\title{
Images for the History of Communication: The First Engravings from the Americas
}

\author{
María del Mar Ramírez-Alvarado \\ Department of Audiovisual Communication, Advertising and Literature, Communication Faculty, University of \\ Seville, Seville, Spain \\ Email: delmar@us.es
}

Received 4 December 2014; accepted 16 January 2015; published 30 March 2015

Copyright (C) 2015 by author and Scientific Research Publishing Inc.

This work is licensed under the Creative Commons Attribution International License (CC BY). http://creativecommons.org/licenses/by/4.0/

(c) (i) Open Access

\begin{abstract}
The purpose of this work is to make an in-depth study of the image as a form of representation of the reality which reflects history in a unique way, and to discuss the different factors that may have impact on the correlation between reality and its representation by an image. For that purpose, the first engravings circulated in Europe of American natives will be used as an example, to determine their characteristics, and their authors. The study demonstrates how the images are determined by the interpretations, beliefs and previous knowledge of the artists or publishers of the 92 studied images, none of whom had direct knowledge of the American reality.
\end{abstract}

\section{Keywords}

America, Communication, Images, Native Americans, Printing

\section{Introduction}

The fundamental study objective of the present article is to delve into the way images give a singular account of the real and imaginary environment in which a society develops at a certain moment in history. In this sense, the images constitute a narration that reflects not only elements of reality, but also the common thought structures of their creators and their contemporaries. The first images circulated in Europe of the American native, from the end of the fifteenth century and throughout the sixteenth century, will be used as examples to determine their characteristics and their authors.

There are different aspects which give importance to this moment in the history of communication and what emerges in Europe in the passage from the fifteenth to the sixteenth century. Two of these aspects are closely related to the image: the invention of movable type printing and the improvement of the techniques of applying engraving to the printed page, fundamentally xylography or wood engraving. The possibility of multiple repro- 
duction of the image produced a definitive rupture with the tradition of the previous centuries in that it allowed knowledge, copied in written form, to be transformed into information accessible to the majority. In this way the press and the engraving facilitated access to the image and, thereby, acted as a hub for an iconographic diversification and densification of great importance. The increase of images was vertiginous and the book market expanded importantly with the reduction of the sale price of the editions, which were achieving larger print-runs. In this respect, a determining factor was that very few people knew how to read in Europe in the sixteenth century, and therein lay the importance acquired by images in popular culture and the rise of illustration of printed books. Even at the end of the seventeenth century, only 29 percent of European adults knew how to read (Burke, 1991: 123).

There is another aspect which is important in this transition from the Middle Ages to the Modern. The development of the artificial perspective, by the artists of the Renaissance, came to be one of the most important pillars of the social order of modernity. The creative vortex of the Renaissance in Europe produced an important break from the mediaeval representations of the visible world: the artist had to pursue the imitation of what was real. For this, apart from having creative talent, it was necessary to know the principles of artificial perspective fed by ideas originating from mathematics and geometry. Since then, these principles have served as guides for the reconstruction, on the objectively bi-dimensional pictorial surface, of a figurative plane in which space was presented as homogeneous and unitarily structured.

As fruit of the historical and cultural conventions from the fifteenth century, the artificial perspective became the reference model for the iconic representations of modernity. The search for realism in the Renaissance resulted in a representation with a high degree of iconicity. The imitation of reality had to be represented in such as way so that "the human eyes are deceived" (as indicated in many treaties). The most perfect painting was that which managed to deceive the observer "making that which is fiction pass for reality".

Against this background, the last vestiges of the mediaeval traditions began to interlace with the diverse changes produced in Europe, and with the transformations in the world order generated as a result of the great transatlantic voyages. And thus there appeared the American continent which needed to be explained in all its dimensions. Through the first contacts of the travellers and navigators, with a reality that was unknown to them, many ideas arose that were strongly related to the old and mediaeval traditions. These first descriptions were included in the letters and first accounts of the navigators and also expressed in diverse images of extraordinary interest which are dealt with in this article. Work was undertaken with engravings that were produced by Europeans from the end of the fifteenth century and during the sixteenth and which, in many cases, achieved wide circulation as illustrations in chronicles of the time or in loose sheets. Such a perspective has been very useful, in that it allowed an approach to the problem of using images to define a reality, previously unknown in Europe, conditioned by the appreciations of those who described that reality for the first time and of those who were its first draughtsmen.

\section{Theoretical Considerations. The American Continent as a New Reference}

The expansion of the world to include a new continent from the end of the fifteenth century, with all its repercussions, created the problem of the conception and definition, through images, of a cultural reality that was unknown in Europe. Almost without exception, the first chroniclers picked-up the ideas of the mediaeval bestiaries and travel books that were familiar to them and which spoke of imaginary beings which populated the new lands.

In his voyage logs Columbus himself confirms understanding the references made by the natives, to men with dog's heads, warrior women and beings with one eye who were dispersed among the remote tropical islands. Evidently, what the Admiral believed he heard from the lips of the Taino people agreed with the characterizations of those monstrous beings familiar in Europe since before the Middle Ages (Colón, 1989). These beings of diverse stamp, protagonists of the legends spread at that time, were now transferred to a remote and unknown setting. The travellers who set foot on the new lands after the arrival of Columbus, contributed to circulating the ideas about those Indies adventurously found to the West and populated with many-coloured monsters. Thus, they did not take long in envisaging Pygmies, Satyrs, Cynocephalos, Cyclopes and Panocios, among others, protected by the jungle greenery of that extensive "New World". On occasion, legends were given a new twist and returned strengthened to Europe. One example is the transformation of the Tehuelche Indians (perhaps the only inhabitants of the southern part of the continent that could have been the origin of the story of the giants, 
with their average height of seventy-two inches) into the stunning giants who swelled the mythical compendium of the American lands.

The representation of the native which circulated within Europe throughout the sixteenth century strongly calls attention in this respect. Initially, this representation adhered to a dual iconographic formula: good savage or cannibal. At first, Columbus himself, and the chroniclers, contributed to spreading that dichotomizing conception of the native as being an innocent of the Golden Age or, on the contrary, as a beastly anthropophagous and concupiscent sodomite. Among many other phrases that can be mentioned, the goodness of the Taino people is expressed by Columbus in the following terms: "They are people, not at all bad nor warlike, naked all, men and women, as their mothers bore them” (Tuesday, 6 November 1492). In the same reports of the first voyage, Christopher Columbus outlines with peculiar nuance the other horrific face of these inhabitants with sweet speech, singular innocence and beautiful forms: "two men displayed that they lacked some pieces of flesh on their body and they gave to understand that the cannibals prepare them as snacks" (Monday, 17 December 1492) (Colón, 1985: 69).

Later, in a communication sent by Columbus to Antonio Torres from the island of La Isabela on 30 January 1494, the Admiral requests a licence from the Catholic Kings so that a sufficient number of caravels leave for the new lands loaded with livestock and tools necessary to work the land: "such things could be paid for in slaves, cannibals, people so fierce and handsome [...] that they would be better than any other slaves" (Colón, 1985: 177). During the fourth voyage, Columbus complements that vision of the Earthly Paradise, described a few years before in his third voyage, when arriving at what he called "land of grace" (the North coast of Venezuela) populated with youths of nice gesture, beautiful bodies, good appearance, astute and ingenious: "another failed people, who ate men: the deformity of their grimace says it” (Colón, 1985: 219).

To this conception is added the story of one of the most widely circulated letters in Europe at the beginning of the sixteenth century, the text of which served as inspiration for a large number of engravings and illustrations and which was even translated into several languages: the well-known missive Mundus Novus sent to the Florentine, Lorenzo di Pierfrancesco de Médici, by Amerigo Vespucci from Lisbon. In this letter, the traveller detailed knowing an Indian who had eaten more than three hundred men. In the houses of a village, the frightened Vespucci saw "salted human flesh hanging from the beams, as we would string up the fat and meat of a pig" (Vespucci, 1986: 62). As will be seen, with time, the debate was accentuated, serving as an informative support to the representation of the inhabitant of the Indies according to the presented models.

The image of the cannibal of the "New World" spread through Europe, under the still current face of the bloodthirsty Tartars and Mongols thirteenth century, barbarous beings, sine lege and without sect who, with time, were seen by Westerners as potential allies in the fight against Islam. Three centuries later, already in the sixteenth, that dual conception of "the other" as angel or as demon would repeat itself in the appreciation of the American native.

The importance of the images of the American native was already clear in the Europe of the sixteenth century. For example, Gonzalo Fernández of Oviedo attempted to personally make some illustrations of the American reality, complaining of his own lack of talent and not having a Leonardo or a Mategna close by to take charge of so necessary a task. The same occurred with Fray Diego de Ocaña, who crossed the American continent in search of alms for his convent of Guadalupe in Extremadura. According to the sketches which are conserved in the Library of Oviedo in Spain, Fray Diego attempted to draw natives in a realistic manner, but seeking greater artistic quality in his drawing, strokes were superimposed until these Indians became figures with European features, dressed in the Spanish fashion, and covered with armour and helmet (García Sáez, 1990: 420-430).

The French also felt this need and, in 1564, they named Jacques Le Moyne de Morgues as official painter of the expedition that Jean Ribault and René de Laudonnière were organizing for the colonization of Florida. Also, an English painter, John White, was chosen by Walter Raleigh to participate in one of the first English incursions into North America, specifically in the settlement of Virginia. The drawings of Le Moyne and the watercolours of John White still survive and are of great importance in understanding the vision of the first European colonists in North America. In these images, of unquestionable ethnological value and without equal in the rest of the continent, the reproduction of certain European standards of decorum and beauty are also seen. As J. H. Elliot indicates, White observed those people "through the eyes of someone who had a direct interest in promoting the process of English colonization, and thus selected those scenes of the life of the natives which contributed to creating the best possible image of America in the minds of possible, future immigrants” (Bry, 1992: 10).

This intention of John White was reinforced by Theodor de Bry in his collection of travel stories, when im- 
proving the details of the drawings of the Englishman through the use of engraving on copper plates. The skilful handling of this technique allowed the sharpening of details and the "Europeanization" of the indigenous characteristics obtained by White in his drawings, in order to make them more appropriate for European consumption. Many of the engravings of Theodor de Bry, inspired by White and Moyne, portray the figures of the natives as Greek and Roman statues.

The works of Theodor de Bry are fundamental because, through engraved images of the highest quality, they managed to consolidate the famous anti-Spanish Black Legend in Europe during the transition from the sixteenth to the seventeenth century. The circulation of the Historia del Mondo Nuovo by the Milanese, Girolamo Benzoni, in volumes four, five and six of the Grands Voyages-Americae contributed to this theme to a great extent. Although this work was published on various occasions throughout the sixteenth century and was translated into several languages, it was never translated into the Spanish, nor printed in Spain, due to its contemptuous references to the Conquistadors. However, it achieved a remarkable impact through the work of the German publisher. The presentation of the sixth volume of the collection of trips of Theodor de Bry, in which the first part of the work of Benzoni is reproduced, says:

There follow authentic illustrations of all the new, strange and extraordinary stories and accounts, which truly happened in the Kingdom of Peru [...]. With the authentic description and explanation of these engravings, put orderly at the foot of each figure. All carefully, delicately and artistically engraved in copper and brought to light again by Theodor de Bry of Liège (Bry, 1992: 216).

Miguel de Montaigne saw Brazilian Indians in the city of Rouen but, as can be read in his writings, he always continued believing in those Tupinambá cannibals that the Europeans knew through the engravings which illustrated the works of the French chroniclers. He would later write an interesting essay entitled, De los caníbales, published in 1580 in the French city of Bordeaux and to which reference will be made later (Montaige, 1965). From this essay it is deduced that the writer had access to different chronicles of the time. The stay of the Brazilian Indians in the French city of Rouen has been documented by many authors. Montaigne's contact with these natives is reviewed by Hugh Honour in The European vision of America (Honour, 1975: 7).

As an example, André Thevet, cosmographer to the King of France, who was in Brazil in the middle of the sixteenth century (and author of La Cosmographie Universelle illustrated with various engravings included in this study) (Thevet, 1982), was opposed to that definition of the native influenced by the idea of the barbarous, irrational, violent and fearsome mediaeval savage, so deeply rooted in the contemporary images (although, more precisely, these characteristics are seen in some of the chalcographies which were included in his work):

... there are many who maintain the absurd opinion that these people who we call savages live in the forests and fields in the manner of beasts, as hairy as bears, deer or lions, even representing them thus in rich paintings; in short, to describe a savage they have given him an abundance of hair from head to foot, as an inseparable accident [...]. On the contrary, the savages [...] leave the belly of their mothers as beautiful and pretty as the children of our Europe (Kappler, 1986: 186).

Such information achieved a wide circulation. The descriptions of the American native made at this time widely determined the European view of later years, as can be observed for example in the different references made to the continent and its inhabitants by various writers (Shakespeare, Hobbes, Prévost, Rousseau, Goethe, Schiller) and by European artists of repute (Goya, Girodet, Delacroix, Doré) who never crossed the Atlantic.

In addition, these descriptions also had a deep influence on the identity of the inhabitants of the American continent themselves. The entry into Western history of the peoples of America was regulated by diverse texts and writings (almost all the information on the natives in the sixteenth century came from Europeans), and by the representations that were based on these accounts. For all that, it would not be until 1537, with the Bull, Sublimis Deus, promulgated by Pope Paul III, when, after difficult controversies which had the terrible inclination to anthropophagy as their excuses, it was finally decreed that the natives were rational beings, true humans who did not have to be reduced to slavery and who were able to receive the faith (however, for a long time, although they could participate in the sacraments, neither the natives nor their children were considered suitable to follow the priesthood) (Paul III, 1537). The slavery of the natives was allowed by Royal Charter in 1503. Later, it would be somewhat regulated in 1512 with the enactment of the Laws of Burgos (Perera, 1993: 25).

This diffusion of the figure of the cannibal had consequences in other spheres. From the fifteenth century the term Caribe (from the Caniba understood by Columbus as the reference made by the Taino Indians to the fearful 
people of the Great Khan) was used to designate the anthropophagous inhabitants of the Antilles and South American north coast. Still today, in the Venezuelan Amazon, ferocious piranhas which live in the Orinoco River are metaphorically called "Caribe" fish.

As the quantity of images and dissertations on the subject shows, the cannibalism of the natives caused deep shock among the Europeans of the sixteenth century. While the existence of fantastic beings in the American continent was gradually discounted, the image of the anthropophagus of human appearance, but with monstrous customs, was gaining ground. If the native were comparable to a monstrous being, then he had to be expressed in images according to the inherited tradition of the Middle Ages, when it was inconceivable to speak of monsters without offering their image. For that reason, the mediaeval texts (and later the incunabula) which spoke of monsters, hybrid beasts and magical beings, are found to be full of images. The fact, as unfolds throughout this research, is that the imagined form is the most significant since it determines what is unknown.

For the Europeans of the sixteenth century, the native, originating from a strange unfamiliar world, constituted a great unknown which was resolved, little by little (and with diverse results), to the extent that the savage (angelical or anthropophagous) became a visual object.

\section{Methodology: The First Xylographic Engravings That Circulated in Europe}

The corpus of the present study consisted of ninety-two images of the American native with the following characteristics:

- All the images are engraved (xylographs or chalcographies).

- All the engravings represent images of the Central and South American native, of his daily life, customs, rites and celebrations.

- The ninety-two engravings were printed from the end of the fifteenth century to the beginnings of the seventeenth century (the first in 1493 and the last in 1613). The printing dates of all of them are known exactly or approximately: fifteenth century: four engravings (4.3 percent); sixteenth century: eighty-five engravings (92.47 percent); seventeenth century: 3 engravings (3.22 percent).

- All these engravings were published in Europe and circulated in loose sheets or as illustrations of maps, letters, chronicles, and works of the time and collections of trips which were written and published at the time.

- Regarding the origin of the engravings, the following cases are found:

- The author of the engraving is the printer or publisher: twenty-three engravings (24.21 percent).

- The author and the printer of the engraving are known (both are different people): three engravings (3.22 percent).

○ Only the printer or the print-shop is known: forty-eight engravings (51.61 percent).

○ Only the author of the engraving is known: six engravings (6.45 percent).

○ The engravings are anonymous and the printer is not known: ten engravings (10.52 percent).

- No reference could be found, although it is probable that it exists: two engravings (2.15 percent).

The ninety-two representations of the American native were grouped in five broad recurrent subjects, defined after a study of the content of each individual image. This classification was the most functional, although it had limitations due the disproportion of images which, to a certain extent, could be appraised among the various thematic groups and the difficulty in some case where the engravings could be included in more than one of these groups.

In general, the images were grouped according to the following themes:

1) First contacts with the navigators, such as Figure 1 and Figure 2: included in this group are the engravings that circulated with diverse incunable editions of La Carta of Christopher Columbus sent to Luis Santángel which had broad circulation at the end of the fifteenth century and the start of the sixteenth.

Total: four engravings (4.3 percent of the total corpus of images).

2) Clothing, objects of adornment and customs: this group includes those images in which special emphasis is given to the physical appearance, rites, festivities and daily life of the natives. The representations of cannibalism and idolatry were excluded: although they are described in chronicles as "customs" of the natives, they have been differentiated as separate groups in our study due to the quantity of images on these themes.

Total: forty engravings (43.01 percent of the total corpus of images).

In order to facilitate their analysis, the forty images on this theme are sub-divided into six sub-groups. These sub-groups of each theme were formed when: 


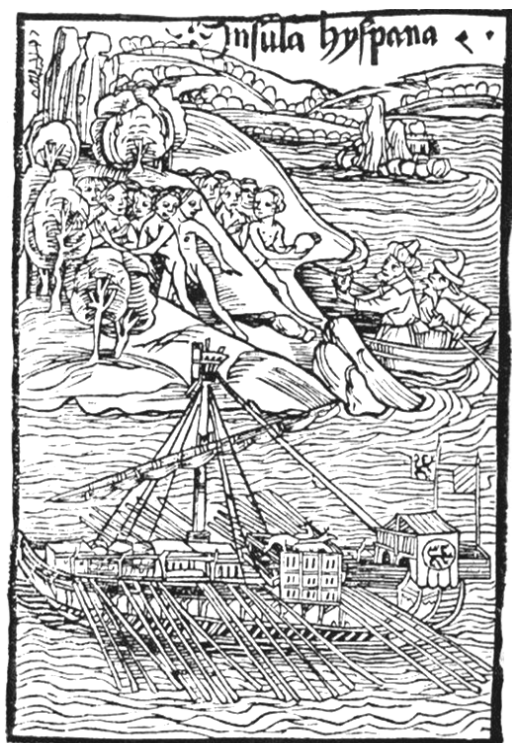

Figure 1. "Insula Hyspana”, De insulis inventis epistola Cristoferi Colom, 1493, Basel.

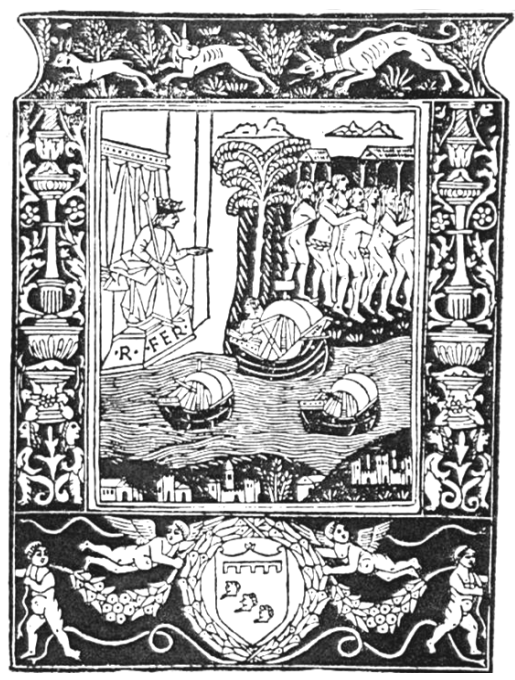

Figure 2. The history of the discovery of the New Indian Island of the Canaries: extract of a letter of Christopher Columbus, 1493, Rome.

- The images had the same textual reference (this is the most frequent case).

- The images had common characteristics regarding the representation of certain motifs.

- The images dealt with the same themes or facts described in different chronicles. These sub-groups are the following:

a) Engravings that have the letters of Amerigo Vespucci as textual references, especially the missive known as Mundus Novus.

b) Images which follow the model of "triumphal march".

c) Engravings which illustrated the Parte primera de la Chrónica del Perú by Pedro Cieza of León. See Figure 3.

d) Engravings which illustrated the chronicle of the German traveller Hans Staden, as shown in Figure 4. Versions of these engravings made by Theodor de Bry.

e) Engravings which illustrated La historia del Mondo Nuovo by the Milanese Girolamo Benzoni. Versions of 


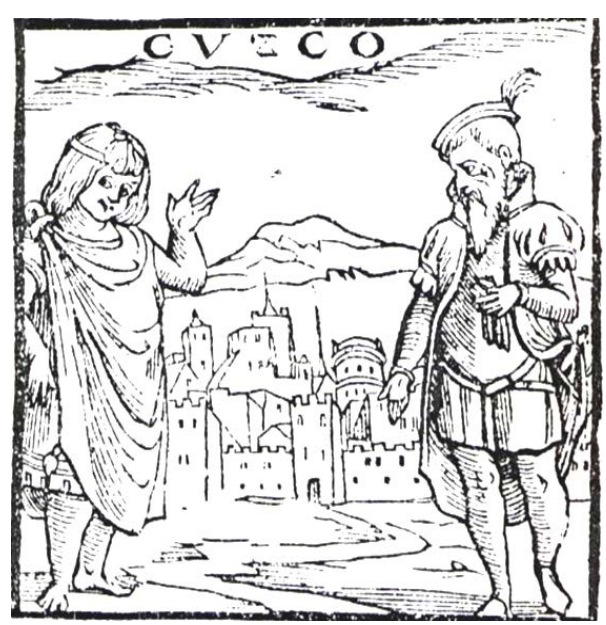

Figure 3. City of Cuzco. Parte primera de la Chrónica del Perú (First part of the Chronicle of Peru) by Pedro Cieza de León. 1553, Seville. M. de Montesdoca, Editor.

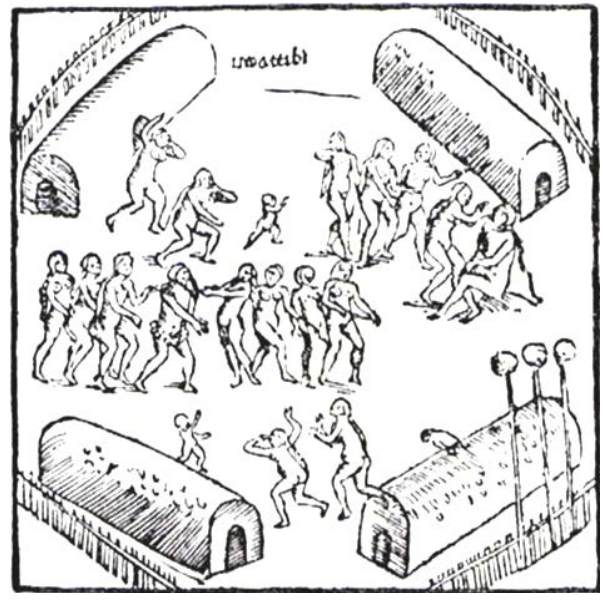

Figure 4. Hans Staden dancing with Tupinambá women. Vera Historia (True Story...) by Hans Staden, 1557, Marburg, Andreas Colben editor.

these engravings made by Theodor de Bry. In addition, a xylograph is included which illustrated the La Historia General de las Indias by Fernández de Oviedo y Valdés (1851) due to its relationship with the engravings of this group.

f) Engravings which illustrated the texts of the French chroniclers, André Thevet and Jean de Léry. Versions of the engravings which illustrated the work of Léry made by Theodor de Bry.

3) Cannibalism: both the direct representations of anthropophagy, and the prior and subsequent preparations to the cannibal rites and ceremonies, have been included in this group.

Total: thirty-one engravings (33.33 percent of the total corpus of images).

The engravings of this theme have been divided into four sub-groups:

a) Engravings which have the missive Mundus Novus of Amerigo Vespucci as a textual reference, as indicated in Figure 5.

b) Engravings which have the Carta de AmerigoVespucci sobre las islas recién halladas en cuatro viajes suyos as a textual reference.

c) Engravings which illustrated the cannibalistic practices of the tribes of the Brazilian coast, for example Figure 6 and Figure 7.

d) Engravings which illustrated the La historia del Mondo Nuovo by GirolamoBenzoni. Versions of these xy- 


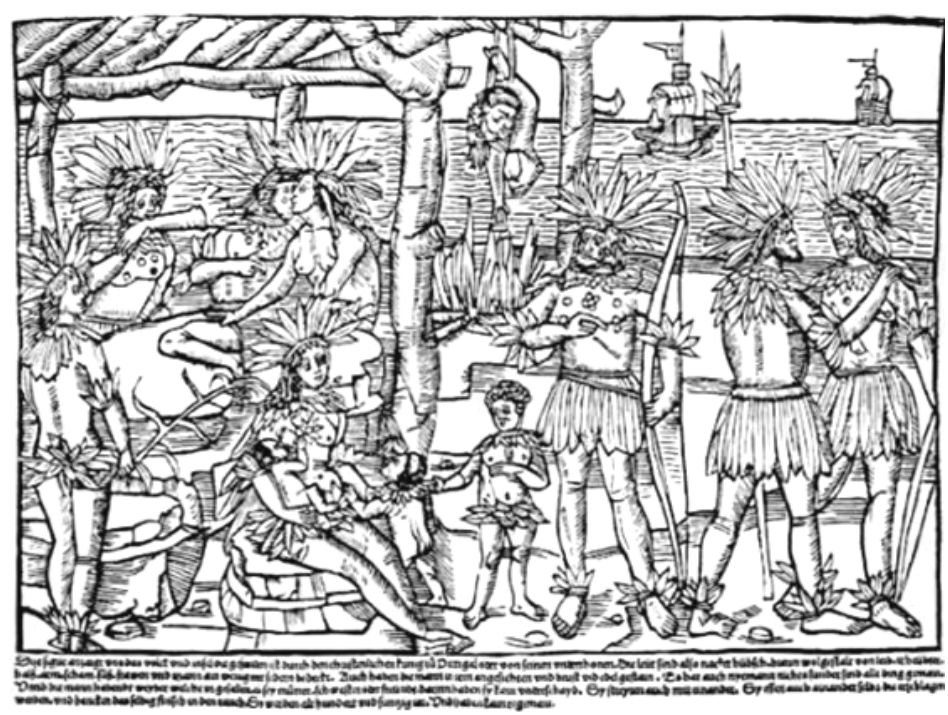

Figure 5. First representation of cannibalism. 1504, Nuremberg or Augsburg. Author/editor: unknown.

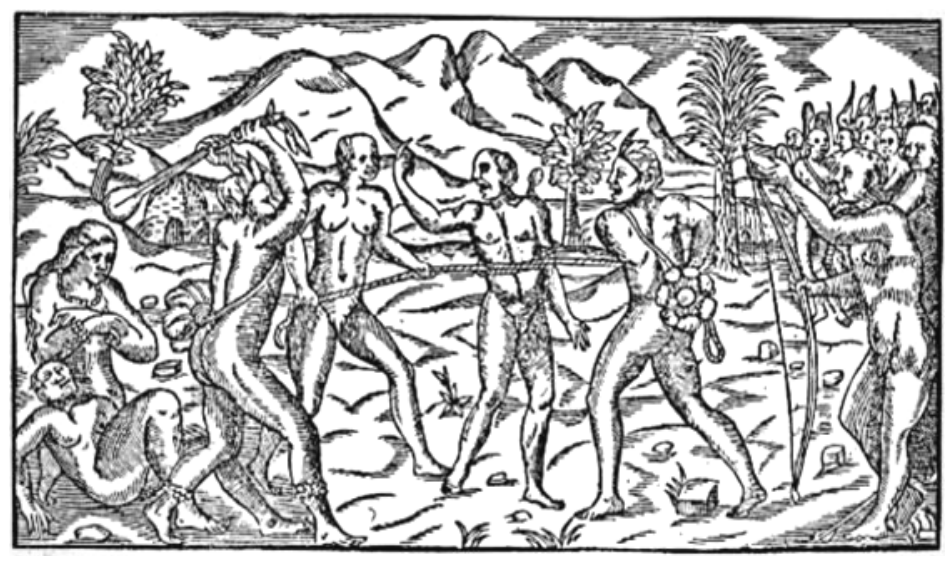

Figure 6. Histoire d'un voyage fait en la terre du Bresil by Jean de Léry, 1578, La Rochelle, Antoine Chuppin editor.

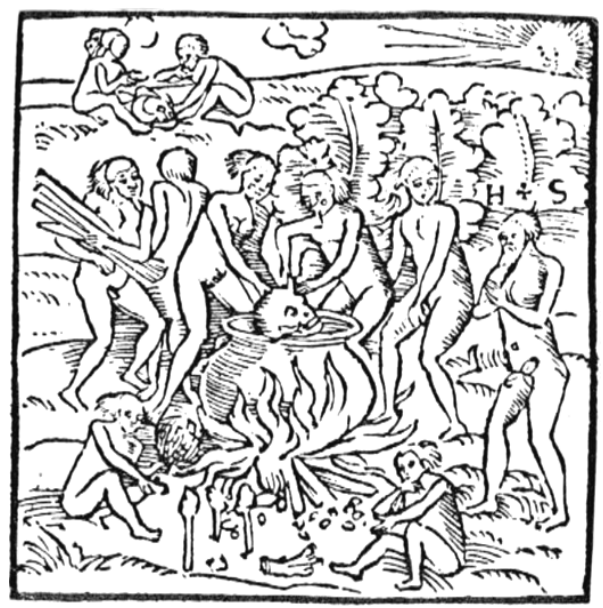

Figure 7. Vera Historia (True Story...) by Hans Staden, 1557, Marburg, Andreas Colben editor. 
lographs made by Theodor de Bry.

4) Idolatry: included in this group, are the images on the cult practices and other religious beliefs of the American natives as in Figure 8.

Total: nine engravings (9.67 percent of the total corpus of images).

5) Allegories of the American continent, such as Figure 9 and Figure 10: the allegorical representation of the continents, common in the old cosmography, reappear in the sixteenth century with the discovery of a continent, unknown until that moment, which required it to be differentiated from the rest and, to this end, represented with its own attributes. From the mid-sixteenth century, diverse allegorical representations of the American continent began to circulate and it is these which are included in this group. The allegories constitute the personification (symbolic representation by means of human figures) of abstract ideas (religious, moral, philosophical, natural, etc.) which are defined through the presence of one or more attributes that characterize them. The attributes are in turn real or conventional objects which serve to recognize the personage and which require, and are united to, the same meaning of the allegory (Esteban Llorente, 1990). For Panofsky (1987), the allegories can be defined

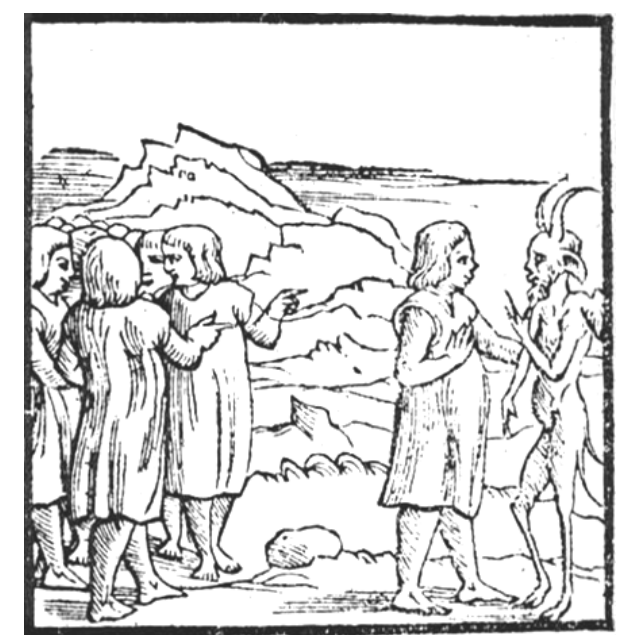

Figure 8. Indians talking with the Parte primera de la Chrónica del Perú (First part of the Chronicle of Peru) by Pedro Cieza de León. 1553, Seville. M. de Montesdoca, Editor, devil.

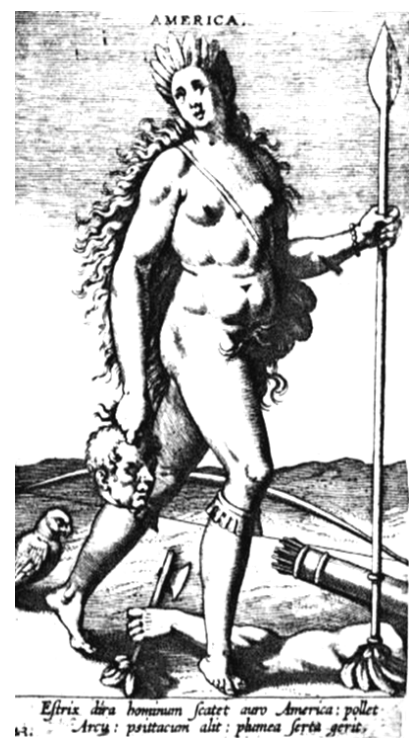

Figure 9. America by Philipp Galle. Antwerp, between 1590/ 1600. Editor: Lepido F. 


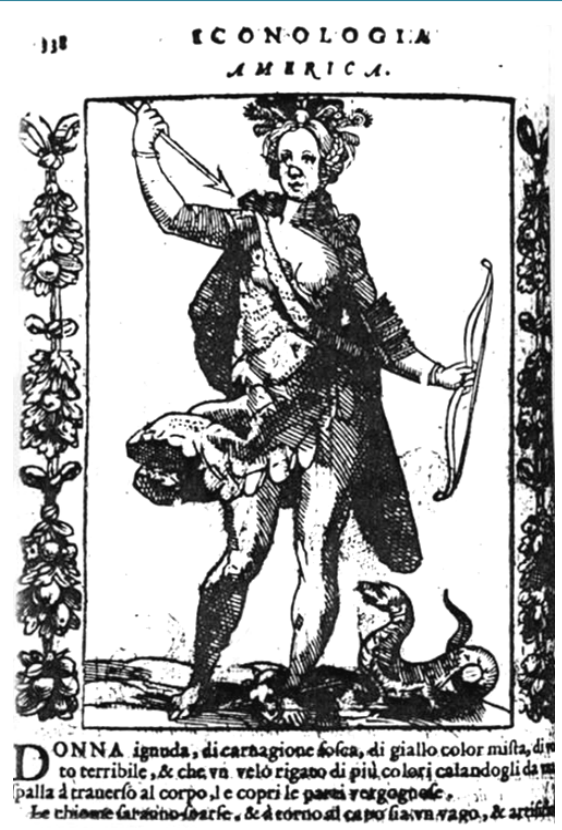

Figure 10. America in Césare Ripa’s Iconology. Rome, 1603. Editor: Lepido F. (Ripa, 1603).

as the combinations of personifications and/or symbols, understood as those images which represent not people or concrete objects, but abstract and general ideas (1987).

Total: nine engravings (9.67 percent of the total corpus of images).

Next, the images were contextualized by: the year and place of execution (city, country) and the author, printer (print-shop) or publisher of the image; the technique of engraving used; degrees of circulation; and commentaries of the time triggered by the images. Subsequently, the textual references of the images were identified, as the great majority of the images of the American native illustrated chronicles, letters and stories of the voyages of the time, as can be seen in the conclusions. Therefore, they represent the passages and facts narrated by the chroniclers and travellers, many immersed in the daily life of the new lands, because there were some authors who had actually been on the American continent.

A further step consisted of the identification of motifs and combinations of motifs (understood as those objects, figures and events that were recognizable in the image) and of the establishment of relationships with the textual references. Along this line, certain aspects have followed the proposal of Erwin Panofsky, developing an iconographic/iconological approach to the analysis of the images of the native, delving into the manner in which, under diverse historical conditions, specific subjects or concepts have been conventionally represented by means of objects, figures and events (Panofsky, 1987: 54-59).

In summary, the following scheme was applied to each group of images:

1) Contextualization of the images (card for each image);

2) Identification of the references of the images;

a) Identification of the textual references of the images;

b) Identification of motifs. Relating them with the textual references.

\section{The Conditioners of the Image. Who Were the European Authors of the First Images of the American Continent?}

In relation to the analysis of the images that have constituted the study corpus of this work, the results referring to the authors of the images are presented in this article, with the idea of delving into the relationship between "what really happened", and the ways in which history is narrated.

The universe of the representations of the American continent had diverse origins. They were partly fed from direct appraisal by navigators, travellers and conquistadors who knew the new lands at first hand. Some of these individuals made small sketches or loose drawings in their logs or on manuscripts in which they recorded their 
impressions (many of which were finally transformed into widely circulated chronicles of the Indies).

Generally, these texts were recreated for publication by people who represented a reality to which they had not had direct access. Such illustrations, in turn, make reference not only to chronicles, but to other texts of the Middle Ages or of antiquity and, in many cases, to the imaginary classical and mediaeval. With the development of the press on the European continent, these works, illustrated by third parties, aroused an enormous interest. An exemplary case, among others, is that of the engravings of the Cartas of Christopher Columbus and Amerigo Vespucci which had abundant editions during the first decades of the sixteenth century. Later, based on these first images of the American native, many other representations were produced.

Thus, the images of the American native which circulated within Europe throughout the sixteenth century that are contained in this studied corpus, to a greater or lesser extent, have three basic points of reference: the reality of the new continent spread in drawings and sketches made by those who had direct access to it; the texts of chronicles of the Indies or other texts (letters, voyage logs, etc.); and, a varied universe of other images.

Notably, the sketches and drawings made directly from nature on the American continent, in as much as they were unique images without copies with little or no circulation, were dismissed from the universe of study, shaped by engravings that could reach a greater circulation in the Europe of the time. Nevertheless, in some cases these images became references for other engraved images which did manage to spread. As such, they have been born in mind when studying the engravings included in the study corpus. We are not aware of engravings made by the authors of texts themselves nor of engravings which, once the printing techniques developed on the American continent, were made and printed in America and which were later circulated in Europe.

It can generally be said that the contemporary letters, voyage logs and chronicles were frequently published in the sixteenth century, in many cases illustrated with engravings. The written texts, in which adventures and diverse episodes were narrated, were then used as basic references for the production of the images. These first chronicles were filled with fantastic stories on the nature and inhabitants of the continent, many of them related to legends and myths that had spread throughout Europe from antiquity.

It was common then that the travellers returned to elements of old traditions in their accounts of their experiences and, in addition, enriched their adventures with descriptions of marvels, natural wonders and diverse curiosities to thereby reinforce the fabulous condition of the places visited. In many cases, the travellers' expectations of what they hoped to find (the customary simplifies the work of recognition, especially when confronted with ambiguous stimuli and in a state of emotional tension) had a determining influence on their first appreciations. For example, Columbus confused manatees with mermaids and thought that the natives spoke of the Cyclopes and Laestrygonians of the region; Vespucci spoke with giants; Federmann found the Ayamanes Indians to be dwarves, as were the "Sachalunas" to Juan de Castellanos (Vespucci, 1986; Federmann, 1986; Castellanos, 1847).

Beyond the perceptive capacity, various conditioners (such as prior knowledge, affection and beliefs) determined these first descriptions, conditioners evidently modelled by the pertinence of these subjects to a certain historical moment and to a certain culture. Columbus considered the "Caniba" to be vassals of the Great Khan and Cieza de León (1984) thought them to be giant antediluvian inhabitants of the continent.

Without doubt, the cultural context of these travellers influenced their attention selectively towards those cultural products which were similar to, or which could be confused with, those with which they were accustomed. The representation of the American native constituted the fruit of that unique and unrepeatable confrontation between real physical properties and characteristics, and the cultural-personal assessment that the travellers made of the native and the American reality. It can be said then that, in this respect, the images of the American native represented what the travellers and chroniclers imagined, thought they saw or hoped to find.

In summary, and to respond to the central objective of this work, it can be said that the new reality of the American continent, and specifically of its inhabitants, was known in Europe through images that had one or more of the following metrics between the reality and its representation:

- Oral descriptions from travellers, navigators, Conquistadors and monks who were on the continent.

- Letters, various writings and printed chronicles (or which circulated in smaller number through hand written copies) of people that directly knew the American reality.

- Chronicles, compilations of travel stories and other writings by people who were never on the continent, as in the case of López de Gomara, and of the Grands Voyages-Americae by Theodor de Bry. Works of great writers, such as, for example, Montaigne, who did not know the reality directly but who wrote about it. An interesting example on the matter is that of the Historia del Nuevo Mundo by Benzoni (1989), who lived in 
America for a time, and in which can be seen the great influence exerted by the Historia General de las Indias by López de Gomara (1984), who never travelled to the continent. Also, the work of Benzoni was published by Theodor de Bry, who incorporated new elements in the illustrations.

- Drawings by artists who were on the continent, such as Jacques Le Moyne de Morgues or John White. Generally, these are small sketches or watercolours which, on some occasions, served as models for other engravings. The chalcographic versions, made by Theodor de Bry of the paintings of Le Moyne and White, in the first two volumes of their collection of trips, serve as examples.

- Engravings and other images from artists who were never on the continent, as is the case with most of the engravings which circulated in contemporary printed works. Generally, these images are also fruit of a first conditioning linked to the accounts that they illustrated. With time, many engravings (and as has been indicated, some drawings) are built on models of other representations.

In relation to the corpus of studied images coming from European editions at the end of the fifteenth century, and in the sixteenth century, it is interesting to note that, apart from that first great conditioning of the travellers' accounts, the images are determined by the expectations, interpretations, beliefs and previous knowledge of the artists themselves who made the engravings. Although in the great majority of cases, the engravings that circulated in texts were from individuals who were on the continent, in none of the ninety-two studied images did the artists or publishers know the American reality directly. This is a peculiar fact that has been proven to be related to the origin of the studied engravings. Generally, in addition to the authors of the images, the printers, publishers or print-shops of the illustrated texts were known. This fact indicates the extent to which the printers could have an even greater importance than the authors of the engraving and, therefore, it reflects the impact of the development of the press on society

It has been possible to appreciate that some of the engravings which have a greater analogy in the representation of native elements and characteristics had their production supervised by the authors of the chronicles. Although this case is infrequent, it indicates a participation of the travellers in the edition of their works which has been taken into account in the study. It could only be verified in the case of the Vera historia by the German, Hans Staden, as the author himself indicated when making reference to some of the illustrations (Staden, 1944).

In the long run, the Europeans of the sixteenth century approached the reality of the American continent through images coming from, at least, a double conditioning: a first, made by the travellers and chroniclers in their texts; and a second, coming from the authors of the images that circulated at the time.

\section{Conclusion}

After the study of the diverse images contained in this work, and specifically of those of the American native, a somewhat paradoxical conclusion has been reached. The more one knows about history and culture, and the deeper one delves into the images of the past, then the clearer becomes the evident difficulty in understanding (and only in a fragmentary manner) the deep and real sense that the images had for their creators and in their environment.

Nevertheless, and here is the paradox, the direct contact with the contemporary images, far removed in time and space, also shows that these represent one of the most valuable documentations of the knowledge and beliefs of the time. The study of diverse images from the same period has offered the opportunity to discern, although with evident difficulty, the mutations, transformations and transferences of the knowledge and the beliefs.

Firstly, what can be noted generally from the analysis of the engravings is the remarkable influence of the imaginary on the life of societies and, in particular, on historical processes. In this regard, the search for mythical places to which reference has been made (Fountain of Eternal Youth, Earthly Paradise, Cibola, St. Brendan’s Isle, etc.) was the motivation and origin of the first explorations of some parts of the American continent. Other myths and mythical personages, known in mediaeval Europe, were related to various areas and determined the adventures and routes of many travellers. Such is the case, for example, of the Amazon warriors described Fray Gaspar de Carvajal (Carvajal, 1986) among others, or of the Patagonian giants, after which the river at the end of the Southern Cone of the continent was named and explored by Francisco de Orellana. During the Middle Ages it was precisely in distant geographic spaces where the limits between the natural and the supernatural were blurred. Thus, due to its distance, America became a propitious land for the proliferation of these mythical tales starring unknown and monstrous beings. 
Secondly, it can be noted that these fantastic beings were described and later represented according to the sum of known elements that, in the end, defined an unknown whole. The typical fauna of the American continent also followed this pattern, which gave rise to the description of common animals as beastly monsters of strange habits. Such descriptions and images managed to reach their own realism through that tendency to use the familiar to represent the unusual. The production of these strange hybrids also resulted from the description of nature in repeated comparison with that known by the travellers, and from the attempts to understand the characteristics of beings which were unknown in Europe. In this way, the constant incorporation of fantastic elements into the physical and behavioural characterization of the most varied species is emphasized. Finally, the rich classical and mediaeval European imagination integrated, and was assuming, American forms or it was fused with autochthonous cultural motifs.

Through the present work it has been possible to verify the importance of the myth as a form of expression and knowledge. In the myth, the understanding of space occupies a fundamental place. In addition, to a certain extent, the mythical areas bear a relation to the diverse needs of the individual or the community. As has been able to be observed in those European myths, revisited with the approach to the American continent, its content translates the importance which, on certain occasions and historical moments, has acquired certain religious, cultural, social problems, etc. For example, it is no wonder a man like Christopher Columbus, so deeply influenced by the mythical-religious thought of the end of the Middle Ages, firmly believed he had arrived at the Earthly Paradise on his third voyage. Similarly, neither is it strange that the uncertainties on the approach to a new continent, inhabited by unknown beings, would have been resolved by drawing comparisons with stories like those of Atlantis, the fantastic islands, the marvellous beings, etc. Indeed, the preoccupation over aging among some Conquistadors had already resulted in years of untiring search for the Fountain of Eternal Youth. However, it can also be stated that, with the effective knowledge of the space and with the real approach to the individuals which occupy it, with discrimination and experience, mythical thought tends to disappear, and it was gradually happening thus on the American continent.

From the first voyage of Christopher Columbus, the European was exposed, paradoxically, to the contemplation of the native according to the two populations described by him: the Tainos, those placid inhabitants of the Antilles; and the "Caniba", savage followers of the Great Khan. This duality, which appears in the work of most of the chroniclers and which had influenced other contemporary stories, defined the engravings of the time to a great extent. In this vein, many of the topics which had been linked to foreigners or inhabitants of other regions, since antiquity, were maintained in the descriptions and representations of the American native which circulated in sixteenth century. On the one hand, the idea of the savages as monstrous beings, assimilable into the other fantastic beings of the Middle Ages, was resurrected. On the other hand, the natives appear related to the Barbarians or irrational Tartars of bloodthirsty customs. This view of foreigners as wild beings, also reproduced the ambiguous concept of the Barbarian peoples inherited from the Greeks and other civilisations which, although suspicion and distrust prevailed, in some cases included a certain idealization of Barbarian lands. These regions, although primitive and removed from civilization, could provide better living conditions to their inhabitants. It is not surprising that they were transformed into the object of the first ethnographic idealizations, hence the polemic between the goodness of primitivism and the decadence of civilisation.

Generally, the way to see the natives and their customs was shaped according to the criteria, beliefs and quests of European culture itself: nakedness was chastely covered with fig leaves; the shabonos and malocas were transformed into mosques and temples; caciques into kings; shamans into witch-doctors, bishops and prelates; bows and arrows into iron swords and axes; loincloths into long robes of feathers; gourds into bowls; the Inca into the sovereign monarch. The natives of the first xylographs, which circulated within Europe, appear represented with their hair curled, abundant beards and thick moustaches, elements which do not correspond with the physical characteristics of the Antillean natives and which, in addition, do not appear mentioned in any of the first letters and chronicles.

However, in spite of this identification of American elements from a European perspective, with the course of the century, various works are found in which very interesting ethnologic descriptions appear. The cannibal rites were recounted in some aspects with sufficient accuracy by the French chroniclers of the sixteenth century, although these did not have the capacity to understand the deep meanings of these ritual behaviours (Lery, 1961). It was surprising to discover, throughout this work, how some of the images managed to capture, sufficiently correctly (taking into account that the authors of the engravings did not know the American reality), the customs, habits, feeding, etc., of the Brazilian Tupi tribes. In general the problem with these engravings is rooted in the 
excessive emphasis given to the cannibalistic practices. The representation of terrible scenes of anthropophagy, loaded with imaginary components, caused other ethnologically important elements about the life of these native tribes to be pushed into the background or to go unnoticed.

\section{References}

Benzoni, G. (1989). Historia del Nuevo Mundo (History of the New World). Madrid: Alianza Editorial.

Bry, T. de (1992). América (1590-1634). Teodoro de Bry. Madrid: Ediciones Siruela.

Burke, P. (1991). La cultura popular en la Europa Moderna (Popular Culture in Modern Europe). Madrid: Alianza Editorial.

Carvajal, G. de (1986). "Relación que escribió Fr. Gaspar de Carvajal, fraile de la Orden de Santo Domingo de Guzmán, del nuevo descubrimiento del famoso río grande que descubrió” (Story written by Fr. Gaspar de Carvajal, brother of theOrder of Santo Domingo de Guzman, about the new discovery of the Famous Large River That He Discovered). La aventura del Amazonas (The Adventure of the Amazonas). Madrid: Historia 16.

Castellanos, J. de (1847). Elegías de varones ilustres de Indias (Elegies of the Illustrious Men of the Indies). Madrid: Biblioteca de Autores Españoles.

Cieza de León, P. (1984). La crónica del Perú (The Chronicle of Peru). Madrid: Historia 16.

Colón, C. (1985). Diario. Relaciones de viaje (Journal. Account of the Voyage). Madrid: Sarpe.

Colón, C. (1989). Cristóbal Colón. Textos y documentos completes (Christopher Columbus. Complete Texts and Documents). Madrid: Alianza Editorial.

Esteban Llorente, J. F. (1990). Tratado de Iconografía (Treatise on Iconography). Madrid: Istmo.

Federmann, N. (1986). Viaje a las Indias del Mar Océano (Voyage to the Indies of the Ocean Sea). Caracas: Editorial Arte.

Fernández de Oviedo y Valdés, G. (1851). Historia general y natural de las Indias, islas y tierra-firme del Mar Océano (General and Natural History of the Indies, Islands and Mainland of the Ocean Sea). Madrid: Real Academia de la Historia.

García Sáez, M. C. (1990). La imagen del indio en el arte español del Siglo de Oro (The Image of the Indian in the Spanish Art of the Golden Age). La imagen del indio en la Europa Moderna (The Image of the Indian in Modern Europe). Seville: School of Hispano-American Studies.

Honour, H. (1975). The European Vision of America. Cleveland: Cleveland Museum of Art.

Kappler, C. (1986). Monstruos, demonios y maravillas a fines de la Edad Media (Monsters, Demons and Marvels at the End of the Middle Ages). Madrid: Akal.

Léry, J. de (1961). Viagem à Terra do Brasil (Voyage to the Land of Brazil). Rio de Janeiro: Biblioteca do Exército Editora.

López de Gomara, F. (1984). Historia general de las Indias y vida de Hernán Cortés (General History of the Indies and Life of Hernán Cortés). Caracas: Biblioteca Ayacucho.

Panofsky, E. (1987). El significado en las artes visuals (Meaning in the Visual Arts). Madrid: Alianza Editorial.

Montaige, M. de (1965). Les essais. Paris: PUF.

Perera, M. A. (1993). La mirada perdida. Etnohistoria y antropología americana del siglo XVI (The Lost View. American Ethno-History and Anthropology of the 16th Century). Caracas: Monte Ávila Editors.

Paul III, P. (1537). Sublimis Deus. www.papalencyclicals.net/Paul03/p3subli.htm

Ripa, C. (1603). Iconología overo descripttione de diverse imagini (Iconology or Descriptions of Various Images). Rome: Appresso Lepido Facii.

Staden, H. (1944). Vera historia y descripcion de unpais de las salvages desnudas feroces gentes devoradoras de hombres sitado en el Nuevo mundo America (True History of a Country of Naked Ferocious Man-Eating People Situated in the New World America). Buenos Aires: Faculty of Philosophy and Ethnographic Museum.

Thevet, A. (1982). Les Singularités de la France Antarctique (The Singularities of the Antarctic France). Paris: Les Temps. Vespucci, A. (1986). Cartas de viaje (Voyage Letters). Madrid: Alianza. 